\title{
PARTISIPASI DAN PENYERAPAN TENAGA KERJA MUSLIMAH DI SEKTOR INFORMAL DALAM MENDUKUNG PERTUMBUHAN EKONOMI YANG BERKELANJUTAN
}

\author{
Dewi Kurniasari \\ UIN Sunan Gunung Djati Bandung \\ Email: dewi_kurniasari@uinsgd.ac.id
}

\begin{abstract}
Abstrak
Walaupun Pertumbuhan ekonomi meningkat secara berkesinambungan akan tetapi dalam pasar tenaga kerja posisi perempuan lebih dirugikan dibanding laki-laki. Sementara perempuan kurang terwakili dalam angkatan kerja, masih banyak dari mereka yang menganggur atau setengah menganggur, yang merupakan pekerja sektor informal dan paruh waktu, pekerja tak dibayar, kelompok pencari kerja, dan yang tidak aktif terlibat dalam pasar kerja. Dalam pembangunan pemberdayaan perempuan yang terjadi selama ini, permasalahan mendasar yang masih dialami adalah rendahnya partisipasi perempuan dalam pembangunan, di samping masih adanya berbagai bentuk praktik diskriminasi terhadap perempuan. Salah satu bentuk diskriminasi adalah pada pekerjaan yang tidak berbayar. Rata-rata perempuan menghabiskan sembilan belas persen waktu mereka setiap harinya melakukan kegiatan tak berbayar, sedangkan laki-laki hanya delapan persen. Hal ini menimbulkan beban berat terhadap perempuan yang harus melakukan pekerjaan tak berbayar dan pengasuhan dengan pekerjaan berbayar. Penelitian ini bertujuan untuk mengkaji partisipasi dan penyerapan tenaga kerja muslimah di sektor informal dalam mendukung pertumbuhan ekonomi yang berkelanjutan. Penelitian ini menggunakan pendekatan kualitatif dengan metode deskriptif dalam menyajikan data-data hasil penelitian secara menyeluruh.
\end{abstract}

Kata Kunci: Tenaga Kerja Perempuan, Ekonomi Berkelanjutan, Sektor Informal.

\section{Abstract}

Although economic growth is increasing continuously, women are more disadvantaged in the labor market than men. While women are underrepresented in the labor force, there are still many of them who are unemployed or not unemployed, who are part-time and informal sector workers, unpaid workers, job-seeking groups, and who are not actively involved in the labor market. In the development of women's empowerment that has occurred so far, the most minor basic problem is women's participation in development, in addition to the existence of various forms of citizenship towards citizenship. One national form is on unpaid work. On average, women spend nineteen percent of their time each day doing unpaid activities, while men only 8 percent. This places a heavy burden on women who have to do paid work and care for paid work. This study aims to examine the participation and absorption of Muslim women workforce in the informal sector in support of sustainable economic growth. This study uses a qualitative approach with descriptive methods in presenting research data as a whole.

Keywords: Women Workers, Sustainable Economy, Informal Sector. 


\section{A. PENDAHULUAN}

Hukum Islam memberi apresiasi tinggi terhadap kesetaraan manusia. Karena semua manusia yang ada di bumi ini berasal dari satu sumber yaitu Allah SWT. Penghormatan atas hak asasi manusia pun sudah diatur secara sempurna dalam Fiqih, Alquran, dan Hadist. Meskipun partisipasi dan perannya meningkat, dalam pasar tenaga kerja, posisi perempuan lebih dirugikan dibanding laki-laki. Sementara perempuan kurang terwakili dalam angkatan kerja, masih banyak dari mereka yang menganggur atau setengah menganggur, yang merupakan pekerja sektor informal dan paruh waktu, pekerja tak dibayar, kelompok pencari kerja, dan yang tidak aktif terlibat dalam pasar kerja.

Meskipun pertumbuhan ekonomi harus terus berkesinambungan, kesempatan kerja yang ada bagi kelompok miskin, terutama perempuan pedesaan yang berpendidikan rendah masih terbatas, sehingga memperlambat laju penurunan kemiskinan. Meskipun partisipasi dan perannya meningkat, dalam pasar tenaga kerja, posisi perempuan lebih dirugikan dibanding laki-laki. Sementara perempuan kurang terwakili dalam angkatan kerja, masih banyak dari mereka yang menganggur atau setengah menganggur, yang merupakan pekerja sektor informal dan paruh waktu, pekerja tak dibayar, kelompok pencari kerja, dan yang tidak aktif terlibat dalam pasar kerja. Dalam pembangunan pemberdayaan perempuan yang terjadi selama ini, permasalahan mendasar yang masih dialami adalah rendahnya partisipasi perempuan dalam pembangunan, di samping masih adanya berbagai bentuk praktik diskriminasi terhadap perempuan. Salah satu bentuk diskriminasi adalah pada pekerjaan yang tidak berbayar. Laporan PBB menekankan bahwa pada setiap kawasan, perempuan dan anakanak perempuan melakukan pekerja tak berbayar dalam jumlah yang besar, di mana di dalamnya termasuk pekerjaan pengasuhan dan pekerjaan rumah tangga. Rata-rata perempuan menghabiskan sembilan belas persen waktu mereka setiap harinya melakukan kegiatan tak berbayar, sedangkan laki-laki hanya delapan persen. Hal ini menimbulkan beban berat terhadap perempuan yang harus melakukan pekerjaan tak berbayar dan pengasuhan dengan pekerjaan berbayar.

Diskriminasi juga terlihat dari kesenjangan antara angka partisipasi tenaga kerja antara laki-laki dan perempuan di berbagai negara di dunia, sekitar 47,2 persen di Timur Tengah, dan lebih dari 40 persen di Asia Selatan. Ketimpangan upah merupakan salah satu bentuk diskriminasi terhadap perempuan. ILO memperkirakan rata-rata kesenjangan upah berdasarkan gender di tingkat global adalah sekitar 23 persen (ILO, 2018).

Di dalam aspek ekonomi, sejak terjadinya krisis ekonomi di Indonesia pada tahun 1998 menyebabkan lapangan kerja semakin sulit. Struktur angkatan kerja masih didominasi oleh angkatan kerja berpendidikan SD ke bawah. Tingkat Partisipasi Angkatan Kerja (TPAK) Indonesia mengalami perkembangan yang berarti pada tahun 1980-2000. TPAK perempuan tahun 1990 (39,00\%) meningkat menjadi 41,53\% pada tahun 2000, sedangkan TPAK lakilaki 71,00\% (1990) meningkat menjadi 71,75\% tahun 2000 (Fakih, 1999).

\section{B. METODE}

Penelitian ini menggunakan metode pendekatan kualitatif deskriptif merupakan upaya memahami berbagai konsep yang ditemukan dalam proses penelitian, dengan menggunakan teknik content analysis (analisis isi) dan riset kepustakaan (library research). Teknik content analysis merupakan metode penelitian yang digunakan untuk mengetahui simpulan dari 
sebuah teks. Atau dengan kata lain, analisis isi merupakan metode penelitian yang ingin mengungkap gagasan penulis yang termanifestasi maupun yang laten. Sedangkan riset kepustakaan (library research) pada penelitian ini menggunakan jenis dan sumber data sekunder yang diperoleh dari hasil penelitian, artikel dan buku-buku referensi yang membahas topik yang berkaitan dengan tema penelitian.

\section{HASIL DAN PEMBAHASAN}

\section{Pekerja Perempuan Sektor Informal dan Pembangunan Ekonomi}

Selama satu dekade terakhir, partisipasi perempuan di pasar tenaga kerja mengalami peningkatan yang cukup nyata, meskipun persentasenya kecil jika dibandingkan dengan lakilaki. Perubahan ini menunjukkan adanya peningkatan peran perempuan yang sangat berarti dalam kegiatan ekonomi di Indonesia. Namun demikian, struktur angkatan kerja perempuan memiliki tingkat pendidikan yang rendah. Dengan demikian, sebagian besar perempuan masih berkiprah di sektor informal atau pekerjaan yang tidak memerlukan kualitas pengetahuan dan keterampilan canggih atau spesifik. Dalam perspektif gender, proporsi tenaga kerja perempuan dan laki-laki di sektor informal adalah $40 \%$ perempuan, dan $60 \%$ laki-laki. Proporsi tenaga kerja perempuan di sektor informal ini mencakup $70 \%$ dari keseluruhan tenaga kerja perempuan (Krisni, 2005).

Pekerjaan perempuan di sektor informal biasanya kurang memberikan jaminan perlindungan secara hukum dan jaminan kesejahteraan yang memadai, di samping kondisi kerja yang memprihatinkan serta pendapatan yang rendah. Namun demikian, meski perempuan mendapat upah hanya $70 \%$ dibandingkan laki-laki, tetapi perempuan telah mengambil porsi $45 \%$ dari seluruh partisipasi angkatan kerja. Dalam area pertanian, perempuan mengalami porsi $48,65 \%$, perdagangan perempuan mengambil porsi $23,44 \%$. Sementara dalam area industri, tenaga kerja perempuan meliputi $13,44 \%$ dan jasa $12,24 \%$.

Pada aspek pertanian, dimana kebanyakan kaum perempuan menjadi tenaga kerja tanpa upah karena merupakan usaha keluarga sebanyak 80\%. Dari data tersebut, dapat dilihat betapa perempuan kurang mendapat akses dan keadilan dalam bidang ekonomi. Perempuan masih banyak melakukan pekerjaan di sektor informal yang tidak memerlukan keahlian dan keterampilan, dan tentunya ini berimplikasi pada perlindungan hukum yang kurang, penerimaan upah yang tidak memadai, belum lagi beban ganda yang dirasakan.

Menurut PBB, hingga tahun 2014, 143 negara telah menjamin kesetaraan antara lakilaki dan perempuan dalam konstitusi mereka. Menempatkan kesetaraan gender pada kerangka hukum dianggap sebagai langkah penting dalam mengakhiri segala bentuk diskriminasi terhadap perempuan.

Masih tingginya proporsi sektor informal dalam perekonomian menjadi tantangan tersendiri dalam mewujudkan pembangunan berkelanjutan. Meskipun jumlah tenaga kerja informal menurun selama periode sepuluh tahun terakhir, namun masih terdapat banyak permasalahan pada sektor informal, di antaranya adalah tidak adanya jaminan hak-hak dan proteksi sosial bagi para pekerjanya (World Bank, 2011; ILO, 2018; Vanek et al., 2014).

Hal ini bertentangan dengan tujuan pembangunan berkelanjutan (SDGs) yang menempatkan pekerjaan layak (decent work) untuk semua sebagai target pembangunan (UN, 2014). Dalam RPJMN 2014-2019, menciptakan pekerjaan layak bagi semua golongan merupakan bagian dari tujuan pembangunan nasional, tidak terkecuali bagi kaum perempuan. 
Besarnya jumlah pekerja wanita sektor informal seharusnya menjadi modal bagi pembangunan ekonomi kreatif masyarakat yang dapat mendukung peningkatan ekonomi bangsa. Untuk menjadi sektor yang diandalkan, pekerjanya juga harus memiliki karakterisitik yang baik, seperti pendidikan tinggi, dan berketerampilan sehingga harapan untuk perbaikan pada sektor informal akan menjadi kenyataan.

\section{Kedudukan Perempuan Dalam Islam}

Bangsa yang maju mengakui perlunya perbaikan kualitas, status, dan peran perempuan dalam pembangunan untuk meningkatkan keadilan sosial dan memenuhi hak-hak azasi manusia yang setara antara perempuan dan pria. Islam adalah sebuah agama yang rahmatan lil 'alamin. Hal ini tercermin dari nilai-nilai kemanusiaan yang terkandung di dalamnya. Keluhuran nilai-nilai kemanusiaan dalam Islam tercermin dengan adanya pengakuan yang tulus dan penghargaan yang tinggi terhadap kesamaan manusia. Semua manusia adalah sama, karena ia berasal dari satu sumber yakni Allah SWT. Yang membedakan manusia yang satu dengan manusia lainnya hanyalah tingkat ketaqwaannya. Kesamaan manusia senantiasa ada dalam jaminan kitab suci Al-Qur'an. Dan sebagai konsekuensi logis dari hal ini, maka setiap individu (laki-laki maupun perempuan) memiliki kewajiban-kewajiban yang harus ditunaikan serta memiliki hak-hak yang harus diterima.

Kitab suci Al-Qur'an lebih dari adil terhadap perempuan. Sebagaimana yang berulang-ulang ditekankan, Al-Quran lah yang untuk pertama kalinya dalam sejarah manusia, telah mengakui perempuan sebagai entitas yang sah dan memberi mereka hak dalam perkawinan, perceraian, harta, dan warisan. Merujuk kepada beberapa ayat Al-Qur'an yang mengindikasikan bahwa perempuan harus diperlakukan secara sama, bahwa Al-Qur'an mengajarkan semua orang beriman itu sama dihadapan Allah, sementara perempuan juga adalah manusia beriman, dan oleh karena itu mereka harus memperoleh status yang setara. Lebih jauh ditekankan oleh Al-Quran dalam Surat At-Taubah:71: "Dan orang-orang beriman, laki-laki dan perempuan, sebagian mereka menjadi penolong sebagian yang lain. Mereka menyuruh berbuat kebaikan, mencegah kemungkaran, mendirikan sembahyang, dan taat kepada Allah dan utusan-Nya. Karena semua ini, Allah akan memberikan rahmat kepada mereka".

Islam memberikan kesamaan hak antara laki-laki dan perempuan termasuk dalam bidang ekonomi. Namun penafsiran yang bias patriarki terhadap teks-teks Alquran dan Sunah menyebabkan perempuan sulit mengakses hak-hak ekonominya secara setara dengan lakilaki. Struktur patriarki melalui pembagian peran di masyarakat telah memarjinalkan perempuan dalam partisipasi ekonomi dan kepemilikan asset ekonomi. Strategi pembaharuan penafsiran keagamaan ini juga dilengkapi dengan pelbagai strategi pemberdayaan ekonomi perempuan yang dapat membantu mereka mengakses hak-hak ekonominya (Hidayah, 2014).

Partisipasi perempuan dalam pembangunan ekonomi tidak hanya untuk meningkatkan kesejahteraan rumah tangga dan menurunkan tingkat kemiskinan tetapi juga merupakan pondasi yang kokoh di sektor lain. Oleh karena itu, perempuan yang berkecimpung dalam kegiatan ekonomi memiliki kontribusi yang unik baik bagi pembangunan ekonomi dan sosial. Beberapa penelitian menyebutkan bahwa perempuan menghabiskan sembilan puluh persen dari pendapatan mereka pada kesehatan dan pendidikan keluarga serta komunitasnya. Dengan berkontribusi pada keuangan rumah tangga dan pembangunan masyarakat, perempuan 
mampu menghasilkan lebih dari sekedar biaya hidup; tetapi juga mendapatkan posisi terhormat di masyarakat. Tidak kalah pentingnya dalam rumah tangga, mereka juga akan mampu mengendalikan isu-isu seperti keluarga berencana dan mencegah pernikahan anak usia dini. Dengan potensi yang dimiliki perempuan tersebut jika mereka diberdayakan secara ekonomi dan intelektualitas, maka hal ini akan sangat efektif bagi pembangunan masyarakat dan bangsa (Trisiyani, 2014).

Dalam hal pembangunan pemberdayaan perempuan, permasalahan mendasar yang masih dialami saat ini adalah rendahnya partisipasi perempuan dalam pembangunan, di samping masih adanya berbagai bentuk praktik diskriminasi terhadap perempuan. Rendahnya kualitas hidup perempuan terjadi di berbagai lini, antara lain sosial budaya, lingkungan, pendidikan, kesehatan, ekonomi, dan politik (Abdullah, 1990).

\section{Mencairnya Diskriminasi Gender Dalam Upah Pekerja}

Terkait kondisi pasar tenaga kerja, upah merupakan indikator mendasar dalam mengukur ketidaksetaraan gender. Ketimpangan upah berbasis gender ini telah lama menjadi perhatian dalam dunia perekonomian. Perbedaan penilaian sosial terhadap tenaga kerja lakilaki dan perempuan sangat tercermin dari upah yang diperoleh. Kesenjangan upah antar gender mencerminkan daya tawar dan pasar tenaga kerja yang berbeda, akses ke pekerjaan layak, keterlibatan yang tinggi sebagai pekerja paruh waktu atau pekerjaan sementara yang umumnya berpenghasilan rendah, dan bahkan diskriminasi gender secara langsung (BPS dan KPPA, 2016). Hal ini bertentangan dengan tujuan pembangunan berkelanjutan (SDGs) yang menempatkan pekerjaan layak (decent work) untuk semua sebagai target pembangunan (UN, 2014). Dalam RPJMN 2014-2019, menciptakan pekerjaan layak bagi semua golongan merupakan bagian dari tujuan pembangunan nasional, tidak terkecuali bagi kaum perempuan.

Selama kurun waktu satu dasawarsa terakhir, jumlah angkatan kerja perempuan memiliki pertumbuhan yang cukup tinggi. Selama periode 2014-2017 saja, angkatan kerja perempuan rata-rata tumbuh $2,09 \%$ per tahun, jauh di atas angkatan kerja laki-laki yang hanya $1,43 \%$ per tahun. Hal ini menunjukkan bahwa semakin banyak kaum hawa yang terlibat dalam memproduksi barang dan jasa. Namun sayangnya status pekerjaan perempuan justru masih banyak bersifat informal. Berdasarkan hasil Survei Angkatan Kerja Nasional (Sakernas) Agustus 2017, persentase perempuan di sektor informal sebanyak 61,37\%, lebih tinggi dari jumlah tenaga kerja laki-laki pada status yang sama yang hanya $54,34 \%$. Kecenderungan tersebut terjadi bertahun-tahun (Gambar 1), diawali dengan sejak terjadinya krisis ekonomi di Indonesia pada tahun 1998 menyebabkan lapangan kerja semakin sulit.

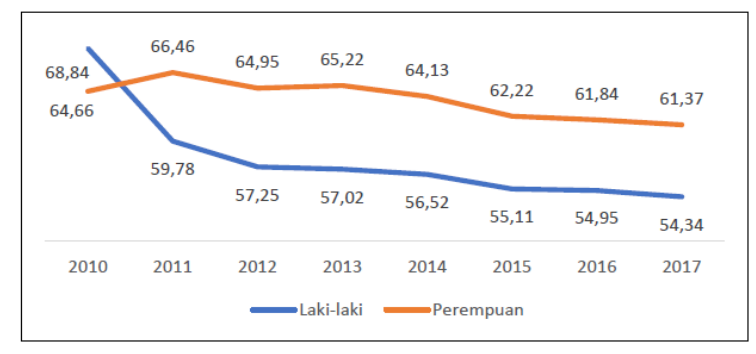

Gambar 1. Perkembangan Tenaga Kerja Informal Indonesia Menurut Jenis Kelamin, 2010-2017

Sumber: BPS, Sakernas (Data diolah) 
Kemudian juga struktur angkatan kerja masih didominasi oleh angkatan kerja berpendidikan SD (Sekolah Dasar) ke bawah. Akan tetapi, tingkat partisipasi Angkatan Kerja (TPAK) Indonesia mengalami perkembangan yang berarti pada tahun 1980-2000. TPAK perempuan tahun 1990 sebesar 39\%, mengalami peningkatan menjadi 41,53\% pada tahun 2000, sedangkan TPAK laki-laki sebesar $71,00 \%$ pada tahun 1990, mengalami peningkatan menjadi 71,75\% tahun 2000 (Fakih, 1999).

Namun demikian, secara komposisi, proporsi perempuan yang menjadi pejabat, manajer, dan tenaga profesional, pada periode 2010-2016 meningkat cukup pesat. Pada tahun 2010, perempuan yang menjadi pimpinan dan tenaga profesional masih berada pada posisi 44,02\%, enam tahun kemudian sudah berada pada posisi 47,59 persen (BPS \& KPPA, 2017). Artinya, secara komposisi jumlah perempuan pada posisi ini semakin mengurangi porsi tenaga kerja laki-laki pada posisi yang sama. Keadaan di atas mencerminkan keadaan Indonesia sebagai negara yang ingin memajukan kaum perempuan khususnya perempuan muslim. Salah satu ukuran lain untuk melihat perbandingan daya saing perempuan adalah Indeks Pembangunan Manusia (IPM) menurut jenis kelamin. Dalam periode 2010-2016, IPM perempuan cenderung lebih rendah dibandingkan laki-laki (hal ini bisa dilihat dalam Gambar 2). Namun, kecepatan capaian IPM perempuan lebih tinggi dari laki-laki (BPS \& KPPA, 2017). Dengan kata lain, kualitas perempuan Indonesia tumbuh lebih pesat.

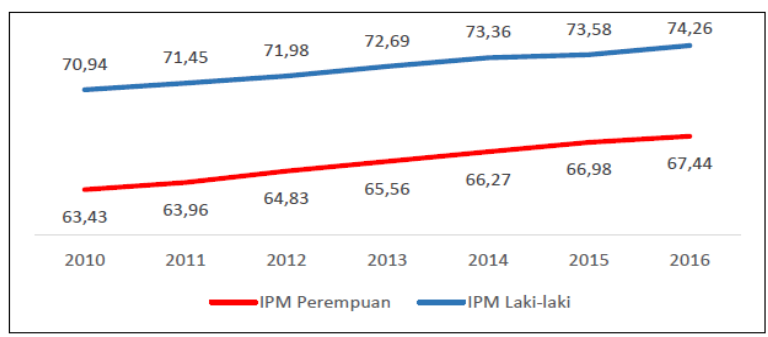

\section{Gambar 2. IPM Indonesia Menurut Jenis Kelamin, 2010-2016}

Sumber: Pembangunan Manusia Berbasis Gender 2017 (BPS dan KPPA, 2017)

Peningkatan kualitas perempuan Indonesia selayaknya diikuti dengan peningkatan kualitas pekerjaan yang dilakukan. Selanjutnya, kualitas tersebut akan mendorong kontribusinya dalam perekonomian. Pada gilirannya akan meningkatkan kesejahteraan yang bersangkutan. Untuk mendukung hal tersebut, Kementerian Pemberdayaan Perempuan dan Perlindungan Anak (KPPPA) melalui program unggulan 3 ENDs berusaha mengakhiri kesenjangan (ketimpangan) akses ekonomi bagi perempuan (BPS \& KPPA, 2016). Persoalan ketimpangan gender dalam ekonomi tidak hanya sekedar terlibat atau tidak terlibatnya perempuan dalam pasar tenaga kerja, tetapi juga ketika perempuan telah memasuki dunia kerja. Faktanya, upah tenaga kerja perempuan cenderung lebih rendah dari laki-laki meskipun sama-sama dalam status formal atau informal (Vanek, Chen, Carré, Heintz \& Hussmanns, 2014; World Bank, 2011).

Sejumlah faktor turut berpengaruh dalam membatasi keterlibatan perempuan dalam jenis pekerjaaan tertentu. Banyak di antara jenis pekerjaan perempuan dicirikan dengan karakteristik seperti paruh waktu, kasual, tidak tetap dan tidak menentu, musiman dan bahkan pekerjaan rumahan (home-based jobs) atau disebut sebagai pekerjaan informal. Mayoritas perempuan yang memilih bekerja di sektor informal disebabkan karena pekerjaan tersebut 
fleksibel dan tidak harus meninggalkan tugas-tugas rumah tangga (OECD, 2008; World Bank, 2011, ILO, 2018; Maloney, 2004).

Ketimpangan gender dalam ketenagakerjaan akan berdampak pada ekonomi. Hasil penelitian yang dilakukan oleh Klasen \& Lamanna (2009), memperlihatkan bahwa ketimpangan dalam kesempatan kerja menghambat pertumbuhan ekonomi, dan pertumbuhan ekonomi yang hilang akibat ketimpangan gender dalam ketenagakerjaan sekitar empat kali lebih besar dibandingkan ketimpangan gender dalam pendidikan. Memberikan kesempatan yang sama kepada perempuan untuk bekerja di sektor formal dapat membuat pasar tenaga kerja menjadi lebih kompetitif (World Bank, 2011). Daya saing tenaga kerja \& pool of talent yang dibutuhkan pengusaha perlu variasi. Sebagaimana diketahui, karakteristik laki-laki dan perempuan berbeda, tentu hal ini akan memberi warna tersendiri dalam dunia kerja. Di sisi lain, pentingnya pelibatan perempuan dalam dunia kerja adalah untuk meningkatkan daya saing global (Seguino, 2000). Masuknya tenaga kerja asing, baik laki-laki maupun perempuan, yang lebih terampil akan semakin membuat pekerja Indonesa kalah bersaing.

Pemberdayaan perempuan dalam pekerjaan formal akan meningkatkan bargaining power dalam lingkup domestik (rumah tangga) dan publik, serta mengurangi kekerasan terhadap perempuan. Berdasarkan hasil Survei Pengalaman Hidup Perempuan Nasional (SPHPN) 2016 yang dilakukan oleh BPS dan KPPPA, kekerasan fisik dan atau seksual lebih banyak dialami perempuan yang berstatus tidak bekerja $(35,1 \%)$. Selain itu, prevalensi perempuan (16-64 tahun) yang pernah atau sedang menikah dan pernah mengalami kekerasan ekonomi selama hidup ada sekitar 24,5 persen. Kekerasan ekonomi ini dilakukan oleh pasangannya.

Jumlah penduduk Indonesia pada tahun 2015 sekitar 255,5 juta orang (Proyeksi Penduduk Hasil SP2010), hampir setengahnya atau tepatnya 49,75 persen merupakan penduduk perempuan. Dengan jumlah tersebut potensi peran perempuan dalam pembangunan sangat besar dan bisa menjadi kontributor yang signifikan dalam pembangunan ekonomi. Perempuan dapat berperan dalam pembangunan ekonomi melalui partisipasi aktif dalam dunia usaha.

Partisipasi perempuan dalam pembangunan ekonomi tidak hanya untuk meningkatkan kesejahteraan rumah tangga dan menurunkan tingkat kemiskinan tetapi juga merupakan pondasi yang kokoh di sektor lain. Oleh karena itu, perempuan yang berkecimpung dalam kegiatan ekonomi memiliki kontribusi yang unik baik bagi pembangunan ekonomi dan sosial. Beberapa penelitian menyebutkan bahwa perempuan menghabiskan sembilan puluh persen dari pendapatan mereka pada kesehatan dan pendidikan keluarga serta komunitasnya. Dengan berkontribusi pada keuangan rumah tangga dan pembangunan masyarakat, perempuan mampu menghasilkan lebih dari sekedar biaya hidup, tetapi juga mendapatkan posisi terhormat di masyarakat. Tidak kalah pentingnya dalam rumah tangga, mereka juga akan mampu mengendalikan isu-isu seperti keluarga berencana dan mencegah pernikahan anak usia dini.

Dengan potensi yang dimiliki perempuan tersebut jika mereka diberdayakan secara ekonomi dan intelektualitas, maka hal ini akan sangat efektif bagi pembangunan masyarakat dan bangsa. Partisipasi perempuan dalam pembangunan ekonomi tidak hanya untuk meningkatkan kesejahteraan rumah tangga dan menurunkan tingkat kemiskinan tetapi juga merupakan pondasi yang kokoh di sektor lain. Oleh karena itu, perempuan yang 
berkecimpung dalam kegiatan ekonomi memiliki kontribusi yang unik baik bagi pembangunan ekonomi dan sosial. Beberapa penelitian menyebutkan bahwa perempuan menghabiskan sembilan puluh persen dari pendapatan mereka pada kesehatan dan pendidikan keluarga serta komunitasnya. Dengan berkontribusi pada keuangan rumah tangga dan pembangunan masyarakat, perempuan mampu menghasilkan lebih dari sekedar biaya hidup, tetapi juga mendapatkan posisi terhormat di masyarakat. Tidak kalah pentingnya dalam rumah tangga, mereka juga akan mampu mengendalikan isu-isu seperti keluarga berencana dan mencegah pernikahan anak usia dini. Dengan potensi yang dimiliki perempuan tersebut jika mereka diberdayakan secara ekonomi dan intelektualitas, maka hal ini akan sangat efektif bagi pembangunan masyarakat dan bangsa (Trisiyani, 2014).

Potensi kaum perempuan dalam membangun perekonomian bangsa dapat melalui partisipasi aktif mereka dalam dunia usaha. Meski sebagian besar pengusaha masih didominasi oleh kaum laki-laki, tingkat kesenjangan gender dalam hal kewirausahaan terindikasikan membaik. Untuk usaha industri mikro kecil (IMK), pelaku usaha perempuan di IMK lebih terlihat pada industri berskala mikro. Kemudian, lebih dari setengah usaha IMK yang dikelola oleh pengusaha perempuan menjalankan kegiatan usahanya di bidang industri pengolahan makanan. Angka tersebut lebih banyak dibandingkan pengusaha laki-laki mikro kecil di bidang yang sama. Meskipun demikian secara umum kondisi IMK masih belum menggembirakan baik untuk kondisi usaha IMK yang dikelola oleh pengusaha laki-laki maupun yang dikelola pengusaha perempuan.

\section{Kondisi Pekerja Wanita Saat Ini Di Sektor Informal}

Di Indonesia penyerapan tenaga kerja selain pada sektor formal juga terjadi pada sektor informal. Sektor informal bahkan merupakan sektor yang lebih besar. Keterbatasan kesempatan kerja pada sektor formal membuat sektor informal menjadi alternatif pilihan bagi para tenaga kerja yang gagal memasuki sektor pekerjaan formal. Ada beberapa faktor yang menyebabkan wanita bekerja. Penelitian Soebyakto \& Armansyah (2016), menunjukkan hal berikut ini: "The dominant factors that cause migrant women working in the informal sector is the desire to help the family income, and flexible working time. The desire to help the family income is the biggest cause of migrant women working in the informal sector with the percentage of $100 \%$ of the number of migrant women working in the informal sector said that the reason they work in the informal sector because they want to help the family income". Dapat dikatakan bahwa penyebab dominan wanita bekerja di sektor informal disebabkan keinginan untuk membantu meningkatkan pendapatan keluarga.

Menurut Risnawati (2016) faktor seperti pendapatan suami yang belum mampu memenuhi kebutuhan keluarga dan banyaknya tanggungan keluarga juga merupakan penyebab wanita memutuskan untuk bekerja pada sektor informal. Dalam hal tenaga kerja, selama ini tenaga kerja wanita (TKW), mendapat konotasi sebagai tenaga kerja kasar, berpendidikan rendah dan biasanya berkaitan dengan pekerjaan-pekerjaan kerumahtanggaan. Sangat mungkin kesan negatif terhadap TKW ini terjadi karena selama ini TKW berkonotasi dengan pembantu rumah tangga, atau baby siter. Mereka ini dalam peraturan dunia perburuhan di Indonesia dikenal sebagai tenaga kerja lapisan bawah. Narnun, dalam pembicaraan kali ini TKW akan diperluas dimensinya, tidak hanya tenaga kerja lapisan bawah, namun juga yang berada di lapisan menengah ke atas. 
Sejak proklamasi kemerdekaan hingga saat ini, terutama di dalam era pembangunan, potensi peranan wanita menjadi sangat penting. Bahkan, jika rnungkin, peranan mereka harus ditingkatkan. Sebab, betapa pun, juga wanita saat ini kedudukannya sudah menjadi semakin baik. Perkembangan ekonomi menuntut wanita harus duduk sejajar dengan pria ketika membicarakan masalah-masalah yang berkaitan dengar isu-isu pembangunan ekonorni.

Menurut Tambunan (1992), tenaga kerja wanita adalah bagian dari penduduk yang secara ekonomis potensial untuk terjun ke dalam pasar tenaga kerja dan bertindak sebagai angkatan kerja. Dengan demikian, tidak lagi dapat dibedakan atas dasar gender, ketika seseorang sudah berada dalam jajaran pasar tenaga kerja. Secara makro, maka setiap orang yang berada dalam jangkauan pasar tenaga kerja, baik pria maupun wanita, akan bersaing ketat untuk memperoleh pekerjaan. Mengingat bahwa dalam jenjang pendidikan saat ini antara pria dan wanita mempunyai kesamaan hak dan kesempatan kerja juga menjadi semakin terbuka bagi wanita, maka partisipasi tenaga kerja wanita terus meningkat dari tahun ke tahun. Pada tahun 1990, tingkat partisipasi angkatan kerja wanita baru 23,65\%, sementara pada tahun 1985 menjadi 39,5\% dan pada tahun 1987 angka itu membengkak menjadi 44,63 $\%$. Proporsi angkatan kerja wanita ini secara relative semakin meningkat dari waktu ke waktu sepertti terlihat dalam tabel berikut ini.

Tabel 1. Komposisi Angkatan Kerja Indonesia Menurut Gender (Dalam \%)

\begin{tabular}{|l|l|l|l|}
\hline Gender & $\mathbf{2 0 0 8}$ & $\mathbf{2 0 1 3}$ & $\mathbf{2 0 1 8}$ \\
\hline Wanita & 37,4 & 38,8 & 40,2 \\
\hline Laki-Laki & 62,6 & 61,2 & 59,8 \\
\hline
\end{tabular}

Sumber: BPS, Proyeksi Angkatan Kerja, berbagai tahun

Atas dasar angka partisipasi yang terus meningkat tersebut, diperkirakan bahwa proporsi angkatan kerja juga akan meningkat dari 37,4\% pada tahun 2008 menjadi 40,2 pada tahun 2018. Angka ini menunjukkan bahwa pada akhirnya angka-angka tersebut akan mendekati titik proporsional perbandingan wanita-pria sebesar 50,3, seperti yang ada saat ini. Hal ini memperkuat kesimpulan bahwa ada kecenderungan bagi wanita untuk berperan lebih besar dalam kegiatan pembangunan ekonomi.

Bahwa pembangunan ekonomi adalah suatu proses bertambahnya pendapatan riil masyarakat dalam jangka panjang, maka sebenarnyalah bahwa upaya-upaya untuk meningkatkan penghasilan masyarakat merupakan obsesi yang sangat kuat. Oleh karena itu, maka pembangunan ekonomi dijadikan titik berat pembangunan jangka panjang. Namun, pembangunan ekonomi bukanlah satu-satunya obsesi. Bidang-bidang lain, misalnya sosial, budaya, pendidikan, dan politik akan pula digarap bersama agar ada keseimbangan.

Sektor informal di Indonesia identik dengan aktivitas ekonomi skala kecil, kurang produktif dan tidak mempunyai prospek yang menjanjikan. Di sisi lain, situasi menjadi rumit karena tidak adanya jaminan hak-hak dan proteksi sosial bagi para pekerja sektor informal (Pitoyo, 2007). Kondisi ini diperparah jika pemerintah lamban memberikan respon, ketidakpastian dalam memberikan perlindungan dan intervensi kebijakan pelaku usaha informal. Dengan demikian, upaya yang perlu diangkat segera adalah bagaimana meningkatkan jumlah tenaga kerja formal khususnya perempuan, sehingga lambat laun tenaga kerja di sektor informal akan mulai berkurang. Oleh karena itu sangat penting untuk mempelajari faktor-faktor apa saja yang diduga kuat membedakan dan mempengaruhi 
dinamika jumlah tenaga kerja formal, sehingga intervensi kebijakan yang diambil dapat tepat sasaran. Program pemberdayaan perempuan juga perlu digencarkan agar perempuan dapat mengontrol nasibnya sendiri. Hingga perempuan akhirnya tidak hanya memiliki kemampuan dan akses yang sama terhadap pendidikan atau sumber daya, tetapi juga memiliki hak untuk berpartisipasi pada segala bidang tanpa rasa takut paksaan dan kekerasan.

\section{Rata-Rata Upah Buruh per Bulan Menurut Lapangan Pekerjaan Utama di 17 Kategori dan Jenis Kelamin}

Rata-rata upah atau gaji buruh atau karyawan atau pegawai yang selanjutnya disebut sebagai rata-rata upah buruh pada Februari 2018 sebesar 2,65 juta rupiah per bulan. Upah tertinggi pada Kategori Jasa Keuangan dan Asuransi, disusul oleh upah tertinggi kedua pada Kategori Pertambangan dan Penggalian, dengan perbedaan yang tidak terlalu signifikan yaitu sebesar 4,13 juta rupiah per bulan, sedangkan upah terendah pada Kategori Jasa Lainnya yaitu sebesar 1,44 juta rupiah per bulan.

Rata-rata upah buruh laki-laki per bulan tertinggi sebesar 4,21 juta rupiah terdapat pada Kategori Jasa Keuangan dan Asuransi, sedangkan terendah pada Kategori Pertanian, Kehutanan, dan Perikanan, yaitu sebesar 1,92 juta rupiah. Rata-rata upah buruh perempuan per bulan tertinggi terdapat pada Kategori Jasa Keuangan dan Asuransi, yaitu sebesar 3,99 juta rupiah, sedangkan terendah pada Kategori Jasa Lainnya yaitu sebesar 1,16 juta rupiah.

Rata-rata upah buruh laki-laki per bulan cenderung lebih tinggi dibanding perempuan, namun pada tiga kategori terjadi sebaliknya, yaitu pada Kategori Konstruksi (laki-laki 2,62 juta rupiah dan perempuan 2,91 juta rupiah), Kategori Transportasi dan Pergudangan (lakilaki 3,12 juta rupiah dan perempuan 3,80 juta rupiah), serta Kategori Real Estat (laki-laki 3,04 juta rupiah dan perempuan 3,21 juta rupiah).

Jika dibandingkan dengan rata-rata upah buruh nasional (2,65 juta rupiah), masih terdapat enam kategori yang memiliki upah di bawah rata-rata upah buruh nasional, yaitu Kategori Konstruksi (2,63 juta rupiah), Kategori Industri Pengolahan (2,48 juta rupiah), Kategori Perdagangan Besar dan Eceran; Reparasi Mobil dan Sepeda Motor (2,16 juta rupiah), Kategori Penyediaan Akomodasi dan Makan Minum (2,10 juta rupiah), Kategori Pertanian, Kehutanan dan Perikanan (1,76 juta rupiah), dan Kategori Jasa Lainnya (1,44 juta rupiah) (BPS, 2018).

\section{Rata-Rata Upah Buruh Per Bulan Menurut Pendidikan Tertinggi Yang Ditamatkan dan Jenis Kelamin}

Dilihat dari tingkat pendidikan pada Februari 2018, sejalan dengan semakin tingginya tingkat pendidikan, rata-rata upah buruh per bulan juga meningkat. Rata-rata upah buruh yang menamatkan pendidikan universitas sebesar 4,42 juta rupiah, hampir 3 kali lipat ratarata upah buruh dengan pendidikan SD ke bawah yang hanya sebesar 1,57 juta rupiah.

Berdasarkan jenis kelamin, terdapat perbedaan rata-rata upah sebulan antara buruh laki-laki dan perempuan. Rata-rata upah buruh laki-laki selalu lebih tinggi daripada perempuan di setiap jenjang pendidikan yang ditamatkan. Pada tingkat pendidikan SD ke bawah, rata-rata upah buruh laki-laki sebesar 1,83 juta rupiah sedangkan perempuan 1,09 juta rupiah. Pada tingkat pendidikan universitas, rata-rata upah buruh laki-laki sebesar 5,22 juta rupiah sedangkan perempuan 3,57 juta rupiah. Selisih terbesar rata-rata upah antara laki-laki 
dan perempuan terdapat pada buruh dengan tingkat pendidikan universitas yaitu sebesar 1,65 juta rupiah.

Padahal kesenjangan upah antar gender dapat menyebabkan berbagai dampak yang tidak hanya bagi perempuan itu sendiri tetapi juga bagi anak-anaknya. Dalam sejumlah penelitian ditemukan bahwa perempuan mempunyai kecenderungan yang berbeda dalam menghabiskan pendapatannya. Mereka akan menyimpan pendapatannya untuk keperluan rumah tangga dan mengalokasikan untuk anak laki-laki atau perempuan secara adil. Dengan demikian, anak laki-laki dan perempuan akan memperoleh keuntungan dan kesempatan pendidikan yang sama, yang nantinya dapat menghilangkan ketimpangan gender di kemudian hari (Haas, 2006).

Peran pemerintah dalam meningkatkan peran perempuan dalam kegiatan ekonomi dan mengurangi kesenjangan gender cukup signifikan. Berbagai perundang-undangan dan hukum dibuat untuk memberikan perlindungan tenaga kerja perempuan, salah satunya berkaitan dengan upah. Pencegahan kesenjangan upah antar gender ini telah diatur dalam Pasal 1 Undang-Undang No. 80 Tahun 1957 yang menjelaskan istilah pengupahan yang sama bagi buruh laki-laki dan wanita untuk pekerjaan yang sama nilainya merujuk kepada nilai pengupahan yang diadakan tanpa diskriminasi berdasarkan jenis kelamin. Penetapan peraturan tersebut menunjukkan keseriusan pemerintah untuk menghilangkan diskriminasi upah antar gender.

Data yang didapat dari BPS, bahwa semakin tinnggi tingkat pendidikan, akan menaikkan tingkat upah para perempuan pekerja. Lulusan perguruan tinggi (Diploma I/II/III) dan Universitas, baik laki-laki maupun perempuan, memiliki rata-rata upah buruh per bulan yang lebih tinggi dibandingkan lulusan SMA ke bawah. Hal ini bisa dilihat dari Tabel 2 berikut ini:

Tabel 2. Rata-Rata Upah Buruh per Bulan Menurut Pendidikan Tertinggi Yang Ditamatkan dan Jenis Kelamin (Rupiah)

\begin{tabular}{|l|c|c|c|}
\multicolumn{4}{|c|}{ Februari 2018 } \\
\begin{tabular}{|l|c|} 
Pendidikan Tertinggi \\
Yang Ditamatkan
\end{tabular} & $\begin{array}{c}\text { Laki- } \\
\text { Laki }\end{array}$ & Perempuan & Laki-Laki +Perempuan \\
\hline SD ke bawah & 1.825 .338 & 1.092 .918 & 1.571 .481 \\
\hline SMP & 1.997 .041 & 1.424 .433 & 1.808 .698 \\
\hline SMA Umum & 2.792 .207 & 1.858 .346 & 2.503 .664 \\
\hline SMA Kejuruan & 2.809 .891 & 2.109 .633 & 2.595 .390 \\
\hline Diploma I/II/III & 4.319 .892 & 2.794 .861 & 3.454 .620 \\
\hline Universitas & 5.219 .178 & 3.568 .841 & 4.417 .217 \\
\hline
\end{tabular}

Sumber: Diolah dari data Survei Angkatan Kerja Nasional (Sakernas) Februari 2018

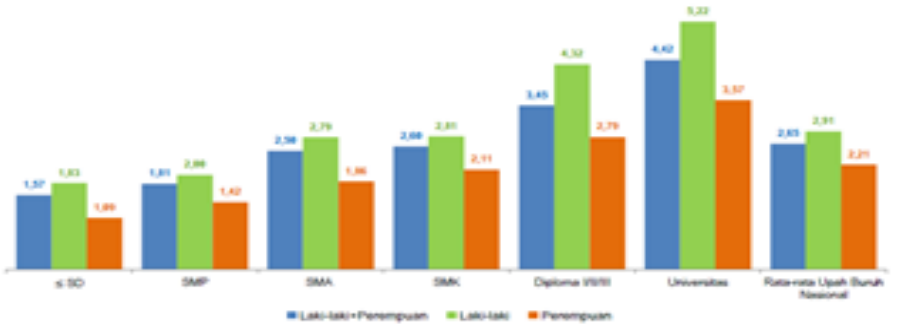

Gambar 3. Rata-Rata Upah Buruh per Bulan Menurut Pendidikan Tertinggi Yang Ditamatkan dan Jenis Kelamin (Juta Rupiah), Februari 2018 
Industri yang sifatnya padat tenaga kerja hendaknya memberikan kesempatan yang lebih besar bagi perempuan. Terlebih lagi saat ini Indonesia sedang mengalami proses transformasi ke sektor industri. Sementara dari sisi individu, perempuan harus diberikan kesempatan setinggi-tingginya dalam pendidikan dan pelatihan kerja. Meningkatkan kesempatan perempuan untuk mengenyam pendidikan tinggi, dapat meningkatkan pertumbuhan ekonomi yang lebih besar. Secara makro, marginal return investasi pendidikan perempuan terhadap ekonomi lebih besar dari laki-laki karena adanya dampak langsung dan tak langsung (Knowles, Lorgelly \& Owen, 2002).

Sinergitas peningkatan kesempatan kerja layak bagi perempuan terutama dengan meingkatkan peran industri padat tenaga kerja dan pendidikan bagi kaum perempuan akan mewujudkan empat tujuan SDGs sekaligus, yaitu Tujuan 5 (mencapai kesetaraan gender dan memberdayakan semua perempuan), Tujuan 8 (mendukung pertumbuhan ekonomi yang inklusif dan berkelanjutan, tenaga kerja penuh dan produktif dan pekerjaan yang layak bagi semua), Tujuan 9 (mendukung industrialisasi yang inklusif dan berkelanjutan), dan pada akhirnya Tujuan 1 (mengakhiri kemiskinan di manapun dalam semua bentuk) akan tercapai.

Dalam teori Human Capital, pencapaian pendidikan yang berbeda bagi laki-laki dan perempuan akan berdampak pada perbedaan upah yang diterima. Kompensasi atau upah atas pekerjaan sangat berdasarkan pada kemampuan dan keterampilan para pekerja. Teori ini menunjukkan bahwa sedikit dan berbedanya modal manusiawi yang dimiliki perempuan dibandingkan laki-laki menyebabkan rendahnya upah perempuan. Hal tersebut berkaitan dengan perbedaan dalam tingkat produktivitasnya. Terlebih lagi bagi wanita yang sudah membentuk keluarga, mereka akan sulit untuk mengembangkan modal manusiawinya (Reimer \& Schroder, 2006).

Kendati perluasaan peluang kerja telah dilakukan selama satu dekade terakhir, dan akses anak perempuan ke dunia pendidikan dan partisipasi di bidang pendidikan berhasil ditingkatkan secara signifikan, namun perempuan masih belum dapat berpartisipasi secara setara di pasar tenaga kerja. Pekerja perempuan tetap terkonsetrasi di perekonomian informal, terutama pekerja rumahan perempuan dan pekerja perempuan di usaha mikro dan kecil (UMK), di mana upah, kondisi kerja, dan keamanan kerja masih buruk. Sekitar sepertiga pekerja perempuan masih terlibat dalam pekerjaan tanpa upah.

Perempuan pun terus menghadapi hambatan besar secara budaya, sosial, ekonomi dan agama dalam memperoleh pekerjaan dan kesetaraan perlakuan di dunia kerja. Pemisahan atau segregasi pekerjaan berdasarkan gender juga cenderung memerangkap perempuan dalam pekerjaan rendahan dengan fungsi pengambilan keputusan yang minimal, sehingga menghambat peluang generasi muda untuk memasuki pasar tenaga kerja (ILO, 2017).

\section{KESIMPULAN}

Peningkatan peran perempuan dalam pembangunan bangsa pada hakekatnya adalah upaya meningkatkan kedudukan, peranan, kemampuan, kemandirian dan ketahanan mental serta spiritual perempuan sebagai bagian tak terpisahkan dari upaya peningkatan kualitas Sumber Daya Manusia (SDM). Pembangunan sebagai suatu kegiatan pengubahan berencana dan direncanakan memiliki tujuan untuk mengadakan perubahan perilaku (kondisi, afeksi, dan ketrampilan) positif dari khalayak sasaran pembangunan yang diharapkan dan dirancang untuk dapat menghasilkan kemanfaatan bagi orang banyak, yaitu masyarakat secara 
keseluruhan (Parawansa, 2013). Berbagai pendekatan pembangunan yang dipergunakan untuk meningkatkan peran perempuan dalam pembangunan menunjukkan bahwa pendekatan pembangunan yang diwujudkan hanya pada perempuan atau hanya pada pria akan mempunyai dampak yang sangat terbatas. Karena itu, kebijakan proyek-proyek pembangunan dialihkan ke arah pendekatan gender yang bertujuan untuk mewujudkan pengintegrasian perempuan dan pria dalam semua sektor pembangunan sesuai dengan potensi serta kebutuhannya masing-masing. Perempuan mempunyai kesempatan yang sama dengan lakilaki untuk berpartisipasi dan berkontribusi di bidang ekonomi.

\section{DAFTAR PUSTAKA}

Abdullah, I. (1990). WANITA KE PASAR: Studi tentang Perubahan Sosial Ekonomi Pedesaan. Populasi, 1(1).

BPS. (2018). Keadaan Ketenagakerjaan Indonesia.

BPS \& KPPPA. (2017). Pembangunan Manusia Berbasis Gender. Jakarta: KPPPA.

BPS \& KPPPA. (2016). Statistik Gender Tematik-Potret Ketimpangan Gender dalam Ekonomi. Jakarta: KPPPA.

Fakih, M. (1999). Analisis Gender dan Transformasi Sosial. Yogyakarta: Pustaka Pelajar.

Haas, S. (2006). Economic Development and the Gender Wage Gap. The Park Place Economist, 14.

Hidayah, N. (2014). Reinterpretasi Hak-Hak Ekonomi Perempuan dalam Islam. AHKAM: Jurnal Ilmu Syariah, 17(1).

ILO. (2013). Mempromosikan Akses Perempuan Atas Pekerjaan yang Layak dan Kesetaraan Kerja di Indonesia. Retrieved from http://www.ilo.org/jakarta/info/public/pr/WCMS201772/langen/index.htm

ILO. (2018). Tujuan Pembangunan Berkelanjutan, Referensi Manual Serikat Pekerja untuk Agenda Pembangunan Berkelanjutan 2030.

ILO. (2018). Women And Men In The Informal Economy: A Statistical Picture. Geneva: ILO.

Klasen. S., \& Lamanna, F. (2009). The Impact of Gender Inequality in Education And Employment On Economic Growth: New Evidence for a Panel of Countries. Feminist Economics 15(3).

Knowles, S., Lorgelly, P. K., \& Owen, P. D. (2002). Are educational gender gaps a brake on economic development? Some cross-country empirical evidence. Oxford economic papers, 54(1), 118-149.

Krisni, M. M. S., (Jurnal Perempuan No 44:2005), Patimah, Dinamika Ekonomi Perempuan dalam Industri Kecil dan Menengah, (Jurnal Equalita. No. 2. Juni 2003).

Maloney, W. F. (2004). Informality Revisited. World Development, 32(7).

OECD. (2008). Gender and Sustainable Development Maximising The Economic, Social And Environmental Role Of Women. Paris: OECD.

Parawansa, K. I. (2013). Pemberdayaan Perempuan Dalam Pembangunan Berkelanjutan. Bali: Kemensos.

Pitoyo, A. J. (2007). Dinamika Sektor Informal di Indonesia: Prospek, Perkembangan dan Kedudukannya dalam Sistem Ekonomi Makro. Populasi, 18(2).

Reimer, D., \& Schroder, J. (2006). Tracing the Gender Wage Gap: Income Differences Between Male And Female University Graduates in Germany. Zeitschrift für Arbeitsmarkt Forschung, 39.

Risnawati. (2016). Peran Ganda Istri yang Bekerja dalam Membantu Ekonomi Keluarga Buruh Perkebunan Kelapa Sawit pada PT. Bumi Mas Agro Kecamatan Sandaran Kabupaten Kutai Timur. eJournal Sosiatri-Sosiologi, 4(3). 
Seguino. S. (2000). Accounting for Gender in Asian Economic Growth. Feminist Economics, $6(3)$.

Soebyakto, B. (2016). Migrant Women Working at Informal Sectors: Empirical Study in Kuto Batu Village, Ilir Timur Ii Palembang City. International journal of humanities and socials science, 6(4), 1-27.

Tambunan. H. (1992). Peranan Wanita dalam Pembangunan. Makalah Lokakarya.

Trisiyani. (2014). Mengapa Wirausaha Wanita Menjadi Kunci Pembangunan Global. Retrieved from http://dberita.com/1170/mengapa-wirausaha-wanita-menjadi-kuncipembangunan-global.

United Nations. (2014). World Survey on the Role of Women In Development 2014 Gender Equality And Sustainable Development. New York: The Research And Data Section Of UN Women.

Vanek, J., Chen, M. A., Carré, F., Heintz, J., \& Hussmanns, R. (2014). Statistics on the informal economy: Definitions, regional estimates and challenges. Women in Informal Employment: Globalizing and Organizing (WIEGO) Working Paper (Statistics), 2, 47-59.

World Bank. (2012). Gender Equality and Development. Washington DC: World Development Report The World Bank. 